\title{
Australian Journal of \\ Correlations between characters and path analysis in sweet sorghum (Sorghum bicolor (L.) Moench) genotypes for juice production
}

\author{
Taniele Carvalho de Oliveira ${ }^{1}$, Marco Antonio Aparecido Barelli ${ }^{2}$, Valvenarg Pereira da Silva ${ }^{2 *}$, Rafhael \\ Felipin-Azevedo ${ }^{2}$, Danilo de Lima Gonçalves ${ }^{2}$, Paulo Ricardo Junges dos Santos ${ }^{2}$, Juliana Parisotto \\ Poletine $^{3}$, Carla Galbiati ${ }^{2}$, Flávio Dessaune Tardin ${ }^{4}$ \\ ${ }^{1}$ Graduate Program in Amazon Biodiversity and Biotechnology, Rede Bionorte, State University of Mato Grosso \\ (UNEMAT), Campus Cáceres-Mato Grosso, Brazil \\ ${ }^{2}$ Faculty of Agricultural and Biological Sciences, State University of Mato Grosso - UNEMAT, Campus Cáceres-Mato \\ Grosso, Brazil \\ ${ }^{3}$ Department of Agronomic Sciences, State University of Maringá - UEM, Umuarama Regional Campus - Umuarama, \\ Paraná, Brazil \\ ${ }^{4}$ Brazilian Agricultural Research Corporation (Embrapa) - Maize \& Sorghum - Sete Lagoas, MG, Brazil
}

\section{*Corresponding author: silvabiologo@hotmail.com}

\section{Abstract}

Sweet sorghum presents stems with juice similar to that of sugar cane, rich in fermentable sugars, that may be used in off-season for sugar and ethanol production optimizing the sugar-ethanol sector. The objective of this work was to determine genetic correlations between characters and perform path analysis between juice volume and its components. Twenty-five sweet sorghum genotypes were evaluated in randomized blocks design with three repetitions and studied variables were: number of days to flowering; plant height; number of stems; weight of green mass; weight of dry mass; number of leaves; diameter of stems; volume of extracted juice and percentage of total soluble solids. In order to verify the existence of variability among the genotypes, data were subjected to variance analysis by F-test. Subsequently, genetic parameters were determined, as soon as genetic correlation estimator's method, performed by t-test, to determine phenotypic correlation and bootstrap method for determining environmental and genetics correlation coefficient. Before performing path analysis a multicollinearity diagnosis was also conducted. The results of genetic correlation and path analysis point weight of green mass as the main variable influencing the juice volume, allowing these characters in indirect selection for increasing juice volume.

Keywords: Genetic correlation; Sucro energetic sector; Genetic Breeding; Juice volume; Saccharine sorghum.

Abbreviations: FLOW_Number of days after planting until the point when $50 \%$ of plants were flowered, $\mathrm{PH}$ _ Plants height (cm), NHS_ Number of harvested stems; PGMWP_ Production of green mass without panicles (kg), PDMWP_ Production of dry mass without panicles $(\mathrm{kg}), \mathrm{NL} \_$Number of leaves, SD_Stem diameter in $(\mathrm{mm})$, JV_ Juice volume $(\mathrm{ml})$ and ${ }^{\circ} \mathrm{BRIX}$ _total soluble solids determining the percentage of total soluble solids.

\section{Introduction}

Sweet or saccharine sorghum (Sorghum bicolor (L.) Moench) features stems with juice similar to that of sugar cane, rich in fermentable sugar and may be used for ethanol production using the same installation of sugarcane (Barcelos et al., 2016). Expansion of sweet sorghum crop in Brazil has broad prospects and admits differentiated models. The preferred expansion model of saccharine sorghum crop is in off-season sugar cane or sugar cane plantations renewal in order to complement the ethanol production, aiming at competitiveness with sustainability, productivity increases, reduction of production costs and greater efficiency in the use of resources and inputs (Durães et al., 2012; Fiorini et al., 2017).

Sweet sorghum breeding programs are primarily focused on obtaining superior cultivars for ethanol yield, with longer period of industrial use, resistance/tolerance to biotic and abiotic stresses and those showing technological features demanded by the market, besides being stable to environmental variations (Silva et al., 2016; Leite et al., 2017; Nida et al., 2019).

Productivity is a complex character resulting from the expression and association of different components (Carvalho et al., 2002). The knowledge of association between characters is of great importance in breeding studies, especially if the selection in one of them presents difficulties, due to the low heritability, or having difficulty in its measuring and identification (Cruz et al., 2012).

Correlation between two characters can be of phenotypic, genotypic or environmental nature, but only the genotype ones involve a combination of inheritable nature, which is of interest for breeding programs (Nogueira et al., 2012). Phenotypic correlation may be directly measured from the 
measures of two characters, in certain numbers of population individuals. Environment causes correlations when two characters are influenced by the same differences in environmental conditions (Cruz et al., 2012).

Magnitudes of these correlations are related to parameters estimates and can range from -1 to +1 , where closer the unit, the greater is selection influence of a character into another (Souza et al., 2008).

Correlations significance is important to all studies, analyses and interpretations, since it allows more precise discernment of correlation estimates, mostly of small magnitudes (Ferreira et al., 2008). However, plant breeder must pay attention to these factors. Therefore, measure and interpretation of a correlation magnitude can lead to errors in selection strategy due to the pleiotropy (when a gene conditions more than one character at the same time) (Vendruscolo et al., 2016).

Correlation is just a measure of association, which does not allow conclusions about cause and effect, not enabling inferences about the kind of association that governs the character pair Y/X (Coimbra et al., 2005; Barili, et al., 2011). In this sense, path analysis, proposed by Wright (1921), allows the partition of correlation coefficient in direct and indirect effects. Thus, with the use of this statistical technique, it is possible to evaluate the environmental effect that interferes on characters interrelation. The objective of this work was to determine genetic correlations between characters and to perform path analysis between juice volume and its components.

\section{Results and Discussion}

\section{Variance analysis}

We observed significant difference among sweet sorghum genotypes $(P<0.01)$ and $(P<0.05)$ for evaluated characteristics (Table 1), demonstrating genetic variability among genotypes. Significant differences indicating genetic variability in sorghum genotypes have also been reported by other researchers Tesfaye (2017), Gebregergs and Mekbib (2020) and Vendruscolo et al. (2020), in which the existence of this genetic diversity is a determining requirement for obtaining genetic gains in plant breeding programs as reported by Sinha and Kumaravadivel (2016).

\section{Genetic Parameters}

Phenotypic and genotypic variances among genotypes showed low magnitude for PH, NHS, PGMWP, PDMWP, NL, $\mathrm{SD}, \mathrm{JV}$ and ${ }^{\circ} \mathrm{Brix}$, with exception for FLOW that presented values of 24.98 and 23.06 for phenotypic and genotypic variances, respectively. This indicates the existence of a high degree of genetic variability among genotypes and suggesting the possibility of success for its selection for this characteristic.

Heritability estimates showed high magnitude FLOW, $\mathrm{PH}$ and NHS with $92.33 \%, 92.26 \%$ and $90.45 \%$, respectively. This reflects considerable presence of the genetic component in the expression of these characters. Mofokeng et al. (2019), considers that high values of heritability indicate minimal environmental influence on the characteristics evaluated. Similar results were observed by Araújo et al. (2014) that assessed genetic parameters in cultivars of grains sorghum in off-season and obtained relatively high heritability values. Nevertheless, it is different from those reported by Jimmy et al. (2017), evaluating ten local sorghum varieties grown in two regions of Kenya. They obtained heritability estimates between 13 and $49 \%$ in the different characteristics that evaluated. Among them, plant height with a percentage of $49 \%$, a value lower than the results obtained in this study.

The index of variation presented high estimates for FLOW, $\mathrm{PH}, \mathrm{NHS}$ and NL with values of 2.00, 1.99, 1.78 and 1.39 respectively. The variation values above 1.0 are favorable in selection process, in accordance with the highest values of heritability. In general, genetic variability among genotypes of assessed sweet sorghum indicates the possibility of success in future selection of these variables. Similar results of this work have been observed by Cunha and Lima (2010) and Diogenes et al. (2012) in sorghum cultivars.

\section{Phenotypic, genotypic and environmental correlation coefficient}

The estimates of phenotypic correlation coefficients $\left(r_{F}\right)$, genotypic $\left(r_{G}\right)$ and environment $\left(r_{E}\right)$ between FLOW, PH, NHS, PGMWP, PDMWP, NL, SD, JV and ${ }^{\circ} B R I X$ characters for 25 genotypes of sweet sorghum ranged from 0.24 to 0.86 ; 0.46 to 1.07 and -0.25 to 0.84 , respectively, with difference in the signal, in the significance and in correlations magnitude for major of evaluated characters (Table 2).

From total of 36 phenotypic correlations, only $63.89 \%$ were significant by t-test, independent of statistical significance (1 or $5 \%$ ). Only $1.82 \%$ of correlations were considered strong; $21.82 \%$ moderate; $34.55 \%$ weak; and $41.81 \%$ very weak. In accumulated percentage of correlations, only $23.64 \%$ were classified between moderate and strong.

From 36 genotypic correlations formed, $55.56 \%$ were significant at 1 or $5 \%$ significance level by Bootstrap method, where $8.34 \%$ were considered very strong; $19.46 \%$ strong and $27.80 \%$ moderate. Genotypic correlations were generally higher than phenotypic and environmental ones, demonstrating a greater contribution of genetic factors in the expression of these characters in relation to environment (Bonett et al., 2006).

The greatest phenotypic, genotypic and environmental correlations with the same sign and significance were observed between PGMWP and PDMWP (0.86) and PGMWP and JV (0.70) characters. According to Rios et al. (2012), phenotypic and genotypic correlations with the same sign and similar magnitudes indicate reliability in using phenotypic correlations for data interpretation, since environmental effect was not really pronounced.

Flowering (FLOW) character presented strong correlation with NL (0.89) and NHS (0.79) and moderate to PDMWP (0.67) and PGMWP (0.65), ranging from very weak and weak to the other characters. Mengesha et al. (2019), for the flowering characteristics reported a positive and significant correlation with plant height, kernel thickness and kernel width. Oliveira et al. (2013), considers that strong to moderate correlations are of greater importance in the early selection of genotypes, serving as a basis for indirect selection. For breeding purposes, it is important to identify between the characteristics of high correlation with the basic variable, the ones with the greatest direct effect on direction to favorable for selection, such that correlated 
Table 1. Variance analysis summary and estimates of phenotypic, genotypic and environment variances, heritability in broad sense and variation index for nine characteristics evaluated in 25 genotypes of sweet sorghum.

\begin{tabular}{|c|c|c|c|c|c|c|c|c|c|}
\hline & \multicolumn{9}{|c|}{ Characteristics $^{1 /}$} \\
\hline & FLOW & $\mathrm{PH}$ & NHS & PGMWP & PDMWP & $\mathrm{NL}$ & SD & $\mathrm{JV}$ & ${ }^{\circ} \mathrm{BRIX}$ \\
\hline & \multicolumn{9}{|c|}{ GENOTYPES MEDIUM SQUARES } \\
\hline $\mathrm{GL}=24$ & $74.94 * *$ & $0.25 * *$ & $466.48^{* *}$ & $3.39 * *$ & $5.11 * *$ & $50.16^{*}$ & $32.08 * *$ & $0.20^{*}$ & $8.40 * *$ \\
\hline AVERAGE & 80.67 & 2.77 & 158.62 & 13.23 & 18.59 & 28.36 & 17.50 & 26844.16 & 16.51 \\
\hline \multirow[t]{2}{*}{ CV(\%) } & 2.97 & 5.04 & 4.21 & 5.33 & 7.51 & 17.19 & 21.22 & 19.72 & 8.91 \\
\hline & \multicolumn{9}{|c|}{ Genetic Parameters } \\
\hline$\hat{\phi}_{f}^{2}$ & 24.98 & 0.08 & 0.02 & 0.10 & 0.06 & 1.13 & 0.03 & 0.07 & 0.04 \\
\hline$\hat{\phi}_{e}^{2}$ & 23.06 & 0.07 & 0.83 & 0.05 & 0.03 & 0.96 & 1.05 & 0.03 & 2.07 \\
\hline$\hat{\phi}_{g}^{2}$ & 5.71 & 0.01 & 0.26 & 0.14 & 0.08 & 0.49 & 1.94 & 0.10 & 2.16 \\
\hline $\mathrm{H}^{2}$ & 92.33 & 92.26 & 90.45 & 52.64 & 56.97 & 85.35 & 61.90 & 48.01 & 74.21 \\
\hline $\mathrm{I}_{\mathrm{V}}$ & 2.00 & 1.99 & 1.78 & 0.61 & 0.66 & 1.39 & 0.74 & 0.55 & 0.98 \\
\hline
\end{tabular}

${ }^{1 /}$ FLOW: number of days after planting until the point when $50 \%$ of plants were flowered; PH: average of plants height in $\mathrm{cm}$; NHS: average number of harvested stems; PGMWP: production of green mass without panicles in kg; PDMWP: production of dry mass without panicles in $\mathrm{kg}$; $\mathrm{NL}$ : average number of leaves; SD average stem diameter in $\mathrm{mm}$; JV: average juice volume in $\mathrm{ml}$ and ${ }^{\circ} \mathrm{BRIX}$ : total soluble solids determining the percentage of total soluble solids. ${ }^{* *}$ and ${ }^{*}$ significance at 1 and $5 \%$ probability level, respectively, by F test.

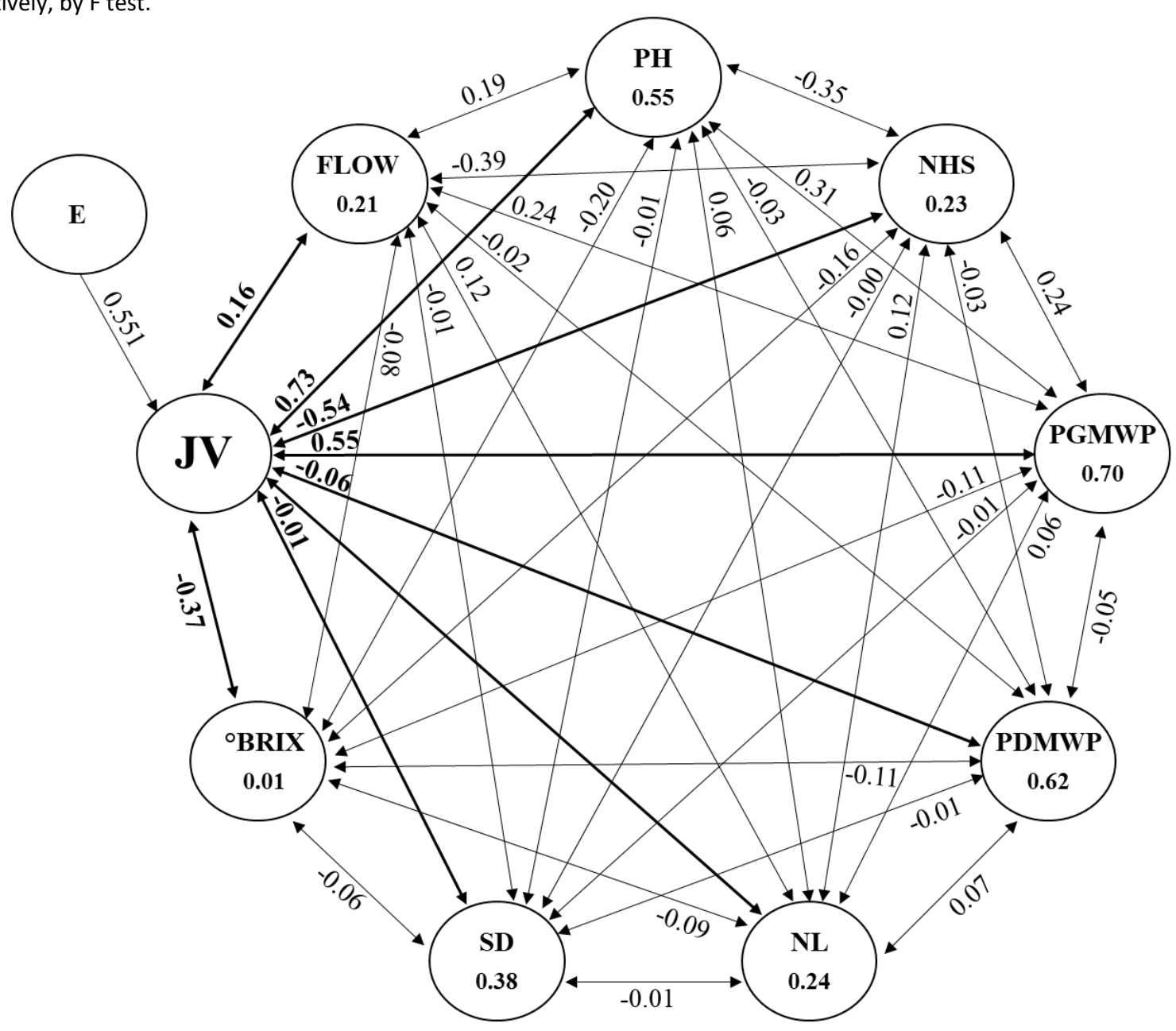

Figure 1. Diagram on the correlations between the explanatory variables and their direct effects on the basic variable in sweet sorghum genotypes. Unidirectional arrows, as well as bold values, indicate the direct effects of the explanatory variables on the basic variable and the effect of the residual variable, respectively. The bidirectional arrows indicate the correlations between the explanatory variables. 
Table 2. Estimates of phenotypic correlation coefficient $\left(r_{F}\right)$, genotypic $\left(r_{G}\right)$ and environment $\left(r_{E}\right)$ between nine characteristics evaluated in 25 sweet sorghum genotypes.

\begin{tabular}{|c|c|c|c|c|c|c|c|c|c|}
\hline Chracters $^{1 /}$ & $R$ & $\mathrm{PH}$ & $\mathrm{NHS}$ & PGMWP & PDMWP & $\mathrm{NL}$ & SD & JV & ${ }^{\circ} \mathrm{BRIX}$ \\
\hline & $r_{F}$ & 0.26 & $0.72 * *$ & $0.43^{*}$ & $0.47 *$ & $0.80^{* *}$ & 0.10 & 0.21 & 0.22 \\
\hline \multirow[t]{3}{*}{ FLOW } & $r_{G}$ & 0.32 & $0.79^{++}$ & $0.65^{+}$ & $0.67^{++}$ & $0.89^{++}$ & 0.19 & 0.39 & 0.26 \\
\hline & $r_{E}$ & $-0.53^{++}$ & -0.04 & -0.09 & -0.09 & 0.11 & -0.21 & $-0.25^{+}$ & 0.04 \\
\hline & $r_{F}$ & & $0.65 * *$ & $0.57 * *$ & $0.60 * *$ & $0.42^{*}$ & $0.32 *$ & $0.55^{* *}$ & $0.53 * *$ \\
\hline \multirow[t]{3}{*}{$\mathrm{PH}$} & $r_{G}$ & & $0.66^{++}$ & $0.75^{++}$ & $0.74^{++}$ & $0.46^{+}$ & 0.29 & $0.66^{+}$ & $0.64^{++}$ \\
\hline & $r_{E}$ & & $0.50^{++}$ & $0.27^{+}$ & $0.35^{++}$ & 0.04 & $0.60^{++}$ & $0.56^{++}$ & 0.09 \\
\hline & $r_{F}$ & & & $0.43^{*}$ & $0.49 * *$ & $0.86 * *$ & 0.23 & 0.23 & $0.43^{*}$ \\
\hline \multirow[t]{3}{*}{ NHS } & $r_{G}$ & & & $0.60^{+}$ & $0.65^{++}$ & $0.97^{++}$ & 0.23 & 0.30 & $0.52^{+}$ \\
\hline & $r_{E}$ & & & 0.10 & 0.12 & 0.06 & $0.35^{+}$ & 0.14 & 0.02 \\
\hline & $r_{F}$ & & & & $0.86 * *$ & $0.43^{*}$ & $0.61 * *$ & $0.70 * *$ & 0.29 \\
\hline \multirow[t]{3}{*}{ PGMWP } & $r_{G}$ & & & & $0.88^{++}$ & $0.60^{+}$ & $0.89^{++}$ & $1.07^{++}$ & 0.42 \\
\hline & $r_{E}$ & & & & $0.84^{++}$ & 0.11 & $0.24^{+}$ & $0.32^{++}$ & 0.09 \\
\hline & $r_{F}$ & & & & & $0.51 * *$ & $0.51^{*}$ & $0.62 * *$ & 0.30 \\
\hline \multirow[t]{3}{*}{ PDMWP } & $r_{G}$ & & & & & $0.70^{++}$ & 0.70 & $0.95^{++}$ & 0.43 \\
\hline & $r_{E}$ & & & & & 0.09 & $0.09^{++}$ & $0.26^{+}$ & 0.07 \\
\hline & $r_{F}$ & & & & & & 0.17 & 0.24 & 0.24 \\
\hline \multirow[t]{3}{*}{ NL } & $r_{G}$ & & & & & & 0.24 & 0.34 & 0.30 \\
\hline & $r_{E}$ & & & & & & -0.00 & 0.07 & 0.03 \\
\hline & $r_{F}$ & & & & & & & $0.24 *$ & 0.16 \\
\hline \multirow[t]{3}{*}{ SD } & $r_{G}$ & & & & & & & 0.30 & 0.21 \\
\hline & $r_{E}$ & & & & & & & $0.03^{++}$ & 0.06 \\
\hline & $r_{F}$ & & & & & & & & 0.00 \\
\hline \multirow[t]{2}{*}{ JV } & $r_{G}$ & & & & & & & & -0.20 \\
\hline & $r_{E}$ & & & & & & & & $0.32^{+}$ \\
\hline
\end{tabular}

${ }^{1 /}$ FLOW: number of days after planting until the point when $50 \%$ of plants were flowered; $\mathrm{PH}$ : average of plants height in $\mathrm{cm}$; NHS: average number of harvested stems; PGMWP: production of green mass without panicles in kg; PDMWP: production of dry mass without panicles in $\mathrm{kg}$; $\mathrm{NL}$ : average number of leaves; SD average stem diameter in $\mathrm{mm}$; JV: average juice volume in $\mathrm{ml}$ and ${ }^{\circ} \mathrm{BRIX}$ : total soluble solids determining the percentage of total soluble solids. ${ }^{* *}$ and ${ }^{*}$ significance at 1 and $5 \%$ probability level, respectively, by t test. ${ }^{++}$and ${ }^{+}$: significance at 1 and $5 \%$ probability level by Bootstrap method.

response by indirect selection is efficient (Severino et al., 2002).

PH correlation with PGMWP (0.75) and PDMWP (0.74) was classified as strong, and for NHS (0.66), JV (0.66), ${ }^{\circ} \mathrm{BRIX}$ (0.64) and NL (0.46) were classified as moderate. Genotypes that showed greater $\mathrm{PH}$, also presented a higher PGMWP, PDMWP, NHS, JV, ${ }^{\circ} \mathrm{BRIX}$ and $\mathrm{NL}$, in expected range. So characters may be used in indirect selection for higher plant. Genotypic and phenotypic correlation estimates of similar magnitude as those observed between the characters infer that the indirect selection for one of the greatest characters results in changes in other character (Benin et al., 2005).

NHS character showed very strong correlation with NL (0.97) and moderate for PDMWP (0.65), PGMWP (0.60) and ${ }^{\circ} \mathrm{BRIX}$ (0.52), indicating that selection for stems number may be conducted through only the selection of that character with easiest selection. According to Teixeira et al. (2012), simultaneous selection of these characters may offer production gains more efficiently.

For PGMWP, the correlation with JV (1.07) was classified as very strong. PDMWP $(0.88)$ and SD (0.89) were classified as strong and moderate for NL (0.60). Similar results were observed by Aguiar et al. (2008) evaluating genotypic and phenotypic correlations between productive characteristics of grain sorghum in Canguaretama, Rio Grande do Norte State, obtaining very strong positive correlations (0.90) between panicle weight and grain weight, having been the phenotypic and genotypic correlations of 1.02 to 0.96 . Such correlations are indicative that heavier panicles result in larger and heavier grains, suggesting that JV, PDMWP, SD and NL may be used as selection criteria for weight increase of green mass.

PDMWP character showed very strong correlation for JV (0.95) and moderated for NL (0.70), indicating that plants selection with major juice volume and major leaves number will result in bigger dry mass weight. From the total of 36 environmental correlations, $41.67 \%$ presented significances at $1 \%$ and $5 \%$ probability level by Bootstrap method with 5000 simulations, showing that environmental factors affect the expression of those characteristics in the same direction. Therefore, the indirect selection is feasible from PH, PGMWP and PDMWP, that are easy to measure and will result in increases to SD, PDMWP and JV, respectively.

Multicollinearity analysis among variables detected weak collinearity to covariates related to mean of juice volume (80.52). According to Coimbra et al. (2005) severe multicollinearity overestimate both correlation coefficients values as the direct effects over the main character estimated through the path analysis. When the degree of multicollinearity is considered weak, it does not constitute serious implications for the analysis.

\section{Direct and indirect effects of primary variables on the basic variable}

The unfolding by path analysis of genotypic correlation coefficients of primary agronomic characteristics FLOW, $\mathrm{PH}$, NHS, PGMWP, PDMWP, NL, SD and ${ }^{\circ} \mathrm{BRIX}$ over basic variable $\mathrm{JV}$ are presented in Figure 1 . Determination coefficient reveals that $69.60 \%$ of juice volume may be explained by the effect of the variables analyzed and the residual effect of 
$55.10 \%$ reflects the contribution of variables model for the basic one. The explanatory model expressed cause and effect relationship between primary variables and juice volume. PGMWP presented the highest correlation with JV (0.70), the high direct effect (0.55) and low indirect effects over this variable. Therefore, genotypes with greater juice volume can be obtained from the selection of plants with greater PGMWP. Similar results were observed by Prasad and Sridhar (2019) and Prasad and Sridhar (2020) where the authors observed high and positive correlations, with a positive direct effect for the characteristic related to productivity in sorghum genotypes.

The fresh matter yield characteristic is complex and results from the association between many characteristics. The intensity of this association allows identifying characteristics that can be used as indirect criteria for selecting productivity (Crevelari et al., 2018).

$\mathrm{PH}$ variable showed correlation of 0.55 and high magnitude (0.73), demonstrating the existence of a strong association between these characters. So, in a process of indirect selection for JV this character may be considered. Similar results were found by Coimbra et al. (2004), Nogueira et al. (2012) and Silva et al. (2008), stating that PH settings between path coefficient of phenotypic correlation have great contribution of this variable for increased productivity. On the other hand, despite PDMWP character have shown the second largest correlation with JV (0.62), presented low direct effect and negative over this character $(-0.06)$. This indicates that such correlations were caused by indirect effects, by FLOW, PH, PGMWP and NL.

According to Lorentz et al. (2006), when correlation coefficient is positive the direct effect is negative or despicable. The correlation will be caused by indirect effects that are observed in the analysis. Similar results were also found by Lopes and Franke (2011) and Hoogerheide et al. (2007) where authors in both works observed high and positive correlations, with direct negative effect, being influenced by indirect effects. NHS character is correlated positively with JV (0.23) and its direct effect is negative (0.54). SD presented a positive correlation (0.38) with JV. However, its direct effect is negative $(-0.01)$. ${ }^{\circ} \mathrm{BRIX}$ percentage also presented significant correlation (0.01), but its direct effect was negative $(-0.37)$, evidencing low contribution of these variables for the basic variable. Results of this work for NHS differ from the results obtained by Silva et al. (2009), where it showed largest direct effects on NHS and SD at flat stage. However, in our study NHS presented low magnitudes, highlighting that is necessary to use selection indices involving both features. Overall, the characters studied differed in its degree of direct influence over JV. PGMWP was the characteristic that presented positive effect and relatively high, indicating the presence of cause and effect, which is related to gains in JV. PH may be considered secondary in influence over JV, though; the presence of direct negative effects indicates the difficulty in selecting only based on behavior of indirect effects.

\section{Materials and methods}

\section{Site description}

The experiment was conducted in Cáceres County, Mato Grosso State, at State University of the Mato Grosso UNEMAT, including the geographical coordinates $16^{\circ} 04$ 'S and $57^{\circ} 39$ 'W at an altitude of 118 meters. Region climate, is Awa type (tropical hot and humid, with dry winter) according to the classification described by Köppen. The annual mean precipitation is around $1,335 \mathrm{~mm}$ and maximum and minimum temperatures in 32 and $21^{\circ} \mathrm{C}$, respectively. The soil of experimental area was classified according to EMBRAPA (2013) as Latosoil red yellow distrophic.

\section{Plant material}

Treatments consisted of twenty-five sweet sorghum genotypes from Genetic Breeding Program belonging to Embrapa Milho and Sorgo, with part of them commercial cultivars and experimental cultivars: BR501, BR505, BRS506, BRS509, CMSXS630, CMSXS634, CMSXS642, CMSXS643, CMSXS644, CMSXS646, CMSXS647, CMSXS648, 201027013, 201027014, 201027015, 201027016, 201027017, 201027018, 201027019, 201027020, BRS601, Sugargraze, V82391, V82392 and V82393.

\section{Experimental design}

The experimental design used was randomized complete blocks with three replications. The experimental units consisted of four plants rows with $5.0 \mathrm{~m}$ long, spaced $0.70 \mathrm{~m}$ from each other, keeping after thinning, nine plants per meter. Two central rows of each plot were considered useful area, where evaluations fulfilled.

\section{Sowing and cultural treatment}

Soil preparation consisted of two light harrowing and subsequently it was conducted manual opening of the grooves. In planting fertilization, we applied $150 \mathrm{~kg} \mathrm{ha}^{-1}$ of chemical commercial formula 20-05-20 $\left(\mathrm{N}-\mathrm{P}_{2} \mathrm{O}_{5}-\mathrm{K}_{2} \mathrm{O}\right)$ and 375 $\mathrm{kg} \mathrm{ha}^{-1}$ of $\mathrm{P}_{2} \mathrm{O}_{5}$ and in cover fertilization $89 \mathrm{~kg} \mathrm{ha}^{-1}$ of $\mathrm{N}$. Sowing was started on December, $19^{\text {th }}, 2012$ and the harvest was concluded April, $11^{\text {th }}, 2013$, when grains were on stage durum/flour.

\section{Characteristics evaluated}

In the useful area of each plot we evaluated the following characters: number of days after planting until the point when $50 \%$ of plants were flowered (FLOW); average of plants height $(\mathrm{PH})$ in $\mathrm{cm}$; average number of harvested stems (NHS); production of green mass without panicles (PGMWP) in kg; production of dry mass without panicles (PDMWP) in $\mathrm{kg}$; average number of leaves (NL); average stem diameter (SD) in $\mathrm{mm}$; average juice volume (JV) in $\mathrm{ml}$ and total soluble solids ( ${ }^{\circ} \mathrm{BRIX}$ ) determining the percentage of total soluble solids.

\section{Statistical analysis}

In order to verify the existence of variability among genotypes, data were subjected to variance analysis of by Ftest. Authors determined the following genetic parameters: phenotypic variance, genotypic variance and environment variance, heritability in broad sense and variation index (Cruz, 2006). It was employed the method of genetic correlation estimators, performed by t-test, to determine the significance of phenotypic correlation, and bootstrap method with 5000 simulations to determine the significance 
of genetic and environmental correlation coefficient (Cruz et al., 2012).

To assess the correlations magnitude, we used the classification proposed by Shimakura and Ribeiro Junior (2012) with the following classes: from 0.0 to 0.19 -very weak; from 0.20 to 0.39 -weak; from 0.40 to 0.69 -moderate; from 0.70 to 0.89 - strong and from 0.90 to 1.00 -very strong.

\section{Path analysis}

Before performing path analysis, we conducted the diagnoses of multicollinearity in $X$ ' $X$ matrix in order to discard redundant characters. Multicollinearity level was established on the basis of condition number (ratio between the largest and the smallest matrix auto value) (Montgomery and Peck, 1982). All statistical analyses were performed with the use of Genes computational program (Cruz, 2013).

\section{Conclusion}

The genotypes present genetic variability that may assist breeding programs with sweet sorghum crop. Results of the genetic correlation and path analysis pointed weight of green mass as the main variable influencing juice volume. These characters may be used in indirect selection for increasing juice volume.

\section{Acknowledgment}

The authors are grateful to Fundação de Amparo à Pesquisa do Estado de Mato Grosso (FAPEMAT) and Coordenação de Aperfeiçoamento de Pessoal de Nível Superior - Brasil (CAPES) - Finance Code 001 for granting a scholarship.

\section{References}

Aguiar EM, Lima JMP, Cunha EE, Castro OPCM, Melo AB, Lucena RBM (2008) Correlações genotípicas e fenotípicas entre características produtivas de sorgo granífero. In: 45a Reunião Anual da Sociedade Brasileira de Zootecnia, 2008, João Pessoa, PB. Revista Brasileira de Zootecnia. Lavras: SBZ.

Araújo BL, Arnhold E, Oliveira Junior, EA, Lima CF (2014) Parâmetros genéticos em cultivares de sorgo granífero avaliados em safrinha. Revista Trópica. 8:51-59.

Barcelos CA, Maeda RN, Anna LMMS, Pereira Junior N (2016) Sweet sorghum as a whole-crop feedstock for ethanol production. Biomass and Bioenergy. 94:46-56.

Barili LD, Vale NM, Morais PPP, Baldissera JNC, Almeida CB, Rocha F, Valentini G, Bertoldo JG, Coimbra JLM, Guidolin AF (2011) Correlação fenotípica entre componentes do rendimento de grãos de feijão comum (Phaseolus vulgaris L.). Semina. 32:1263-1274.

Benin G, Carvalho FIF, Oliveira AC, Hartwig I, Schmidt D, Vieira EA, Valério IP, Silva JG (2005) Estimativas de correlações genotípicas e de ambiente em gerações com elevada frequência de heterozigotos. Ciência Rural. 35:523-529.

Bonett LP, Gonçalves-Vidigal MC, Schuelter AR, Vidigal Filho PS, Gonela A. Lacanallo G F (2006) Divergência genética em germoplasma de feijoeiro comum coletado no estado do Paraná, Brasil. Semina. 27:547-560.
Carvalho CGP, Arias CAA, Toledo JFF, Oliveira MF, Vello NA (2002) Correlações e análise de trilha em linhagens de soja semeadas em diferentes épocas. Pesquisa Agropecuária Brasileira. 37:311-320.

Coimbra JLM, Benin G, Vieira EA, Oliveira AC, Carvalho FIF, Guidolin AF, Soares AP (2005) Consequências da multicolinearidade sobre a análise de trilha canola. Ciência Rural. 35:347-352.

Coimbra JLM, Guidolin AF, Almeida ML, Sangoi L, Ender M, Merotto Júnior A (2004) Análise de trilha dos componentes do rendimento de grãos em genótipos de canola. Ciência Rural. 34:1421-1428.

Crevelari JA, Durães NRL, Bendia LCR, Vettorazzi JCF, Entringer GC, Ferreira Júnior JA, Pereira MG (2018) Correlations between agronomic traits and path analysis for silage production in maize hybrids. Bragantia. 77:243252.

Cruz CD (2006) Programa Genes - Análise multivariada e simulação. 1. ed. Viçosa, MG: UFV,(1): 175 p.

Cruz CD (2013) GENES - a software package for analysis in experimental statistics and quantitative genetics. Acta Scientiarum. 35:271-276.

Cruz CD, Regazzi AJ, Carneiro PCS (2012). Modelos biométricos aplicados ao melhoramento genético. Viçosa, MG: UFV, $514 \mathrm{p}$.

Cunha EE, Lima JMP (2010) Caracterização de genótipos e estimativa de parâmetros genéticos de características produtivas de sorgo forrageiro. Revista Brasileira de Zootecnia. 39:701-706.

Diógenes CN, Medeiros AC, Gonçalves RJS, Assis LCSLC, Lima HFF, Sousa WB, Costa M KO (2012) Desempenho de cultivares de sorgo com potencial forrageiro para o Vale do Açu-RN. Revista Científica de Produção Animal. 14:2931.

Durães FOM, May A, Parrella RAC (2012) Sistema Agroindustrial do Sorgo Sacarino no Brasil e a Participação Público-Privada: Oportunidades. Perspectivas e Desafios. Embrapa Milho e Sorgo: Sete Lagoas. 77 p.

EMPRESA BRASILEIRA DE PESQUISA AGROPECUÁRIA EMBRAPA. (2006). Centro Nacional de Pesquisa do Solo. Sistema brasileiro de classificação de solos. 2.ed. Rio de Janeiro, Embrapa Solos, 306p.

Ferreira A, Cruz CD, Vasconcelos ES, Nascimento M, Ribeiro MF, Silva MF (2008) Utilização de bootstrap nãoparamétrico para avaliação de correlações fenotípicas. genotípicas e ambientais. Acta Scientiarum Agronomy. 30:657-663.

Fiorini IVA, Pinho RGV, Pereira HD, Moraes JPM, Santos JPR, Borges ID, Pires LPM (2017) Plants population and harvesting times influence in saccharine sorghum BRS 506 production. Revista Agrogeoambiental. 9:33-46.

Gebregergs G, Mekbib F (2019) Estimation of genetic variability, heritability, and genetic advance in advanced lines for grain yield and yield components of sorghum [Sorghum bicolor (L.) Moench] at Humera, Western Tigray, Ethiopia. Cogent Food \& Agriculture. 6:1-6.

Hoogerheide ESS, Vencovsky R, Farias FJC, Freire EC, Arantes EM (2007) Correlações e análise de trilha de caracteres tecnológicos e a produtividade de fibra de algodão. Pesquisa Agropecuária Brasileira. 42:1401-1405.

Jimmy ML, Nzuve F, Flourence O, Manyasa E, Muthomi J (2017) Genetic variability, heritability, genetic advance and trait correlations in selected sorghum (Sorghum bicolor L. Moench) varieties. International Journal of Agronomy and Agricultural Research. 11:47-56. 
Leite PSS, Fagundes TG, Nunes JAR, Parrella RAC, Durães NNL, Bruzi AT (2017) Association among agro-industrial traits and simultaneous selection in sweet sorghum. Genetics and Molecular Research. 16:1-10.

Lopes RR. Franke LB (2011) Correlação e análise do coeficiente de trilha dos componentes do rendimento de sementes de grama-forquilha. Revista Brasileira Zootecnia. 40:972-977.

Lorentz LH, Fortes FO, Lúcio AD (2006) Análise de trilha entre as variáveis das análises de sementes de espécies florestais exóticas do Rio Grande do Sul. Revista Árvore, 30:567-574.

Mengesha GH, Hailemariam FM, Mindaye TT, Lakew B, Verma RPS (2019) Correlation and path analysis of yield, yield contributing and malt quality traits of Ethiopian sorghum (Sorghum bicolor (L.) Moench) genotypes. African Journal of Plant Science. 13:209-2020.

Mofokeng MA, Shimelis H, Laing M (2019) Genetic variability, heritability and genetic gain for quantitative traits in South African sorghum genotypes. Australian Journal of Crop Science. 13:1-10.

Montgomery DC, Peck EA (1981) Introduction to linear regression analysis. New York: J. Wiley, 504p.

Nida H, Girma G, Mekonen M, Lee S, Seyoum A, Dessalegn K, Tadesse T, Ayana G, Senbetay T, Tesso T, Ejeta G, Mengiste $T$ (2019) Identification of sorghum grain mold resistance loci through genome wide association mapping. Journal of Cereal Science. 85:295-304.

Nogueira APO, Sediyama T, Sousa LB, Hamawaki OT, Cruz CD, Pereira DG, Matsuo E (2012) Análise de trilha e correlações entre caracteres em soja cultivada em duas épocas de semeadura. Bioscience Journal. 28:877-888.

Oliveira RAD, Daros E, Resende MDVD, Bespalhok Filho JC, Zambon JLC, Ruaro L (2013) Early selection in sugarcane family trials via BLUP and BLUPIS procedures. Acta Scientiarum. Agronomy. 35:427-434.

Prasad BVV, Sridhar V (2019) Studies on genetic variability, correlation and path analysis in yellow pericarp sorghum [Sorghum bicolor (L.) Moench] genotypes. International Journal of Current Microbiology and Applied Sciences. 8:367-373.

Prasad BVV, Sridhar V (2019) Assessment of variability, correlation and path analysis for yield and yield related traits in yellow pericarp sorghum germplasm lines [Sorghum bicolor (L.) Moench]. Journal of Pharmacognosy and Phytochemistry. 9:870-873.

Rios SA, Borém A, Guimarães PEO, Paes MCD (2012) Análise de trilha para carotenoides em milho. Revista Ceres. 59:368-373.Severino LS, Sakiyama NS, Pereira AA, Miranda
GV, Zambolim L, Barros UV (2002) Associações da produtividade com outras características agronômicas de café (Coffea arabica L. Catimor). Acta Scientiarum Agronomy. 24:1467-1471.

Shimakura SE, Ribeiro Júnior PJ (2012) Estatística Descritiva: interpretação do coeficiente de correlação. Departamento e Estatística da UFPR. Available em: <http://leg.ufpr.br/ / ce003/ce003/node8.html>. Acesso em: 08 de June de 2020.

Silva AF, Ferreira OE, Costa GHG, Montijo NA, Mutton MA, Mutton MJR (2016) Technological quality of sweet sorghum processed without panicles for ethanol production. Australian Journal of Crop Science. 10:15781582.

Silva FL, Pedrozo CA, Barbosa MHP, Resende MDV, Peternelli LA, Costa PMA, Vieira M S (2009) Análise de trilha para os componentes de produção de cana-de-açúcar via blup. Revista Ceres. 56:308-314.

Silva MA, Lira MA, Santos MVF, Dubeux Junior JCB, Cunha MV, Freitas EV (2008) Análise de trilha em caracteres produtivos de Pennisetum sob corte em Itambé, Pernambuco. Revista Brasileira de Zootecnia. 37:11851191.

Sinha S, Kumararavadivel N (2016) Understanding Genetic Diversity of Sorghum Using Quantitative Traits. Scientifica. 2016:1-8.

Souza ARR, Miranda GV, Pereira MG, Ferreira PL (2008) Correlação de caracteres de uma população crioula de milho para sistema tradicional de cultivo. Revista Caatinga. 21:183-190.

Teixeira DHL, Oliveira MSP, Gonçalves FMA, Nunes JAR (2012) Correlações genéticas e análise de trilha para componentes da produção de frutos de açaizeiro. Revista Brasileira de Fruticultura, 34:1135-1142.

Tesfaye K (2017) Genetic diversity study of sorghum (Sorghum bicolor (L.) Moenc) genotypes, Ethiopia. Acta universitatis sapientiae agriculture and environment. 9:4454.

Vendruscolo TPS, Barelli MAA, Castrillon MAS, Silva RS, Oliveira FT, Corrêa CL, Zago B W, Tardin FD (2017) Correlation and path analysis of biomass sorghum production. Genetics and Molecular Research, 15:1-10.

Vendruscolo TPS, Silva VP, Felipin-Azevedo R, Silva, RS, Castrillon MAS, Corrêa CL, Tardin FD, Barelli MAA (2020). Genetic divergence in biomass sorghum genotypes through agronomic and physical-chemical characters. Research, Society and Development. 9:1-16.

Wright, S. (1921). Correlation and causation. Journal of Agricultural Research, 20:557-585. 